\title{
Communist history, police history and the archives of British state surveillance
}

\section{Document Version}

Accepted author manuscript

Link to publication record in Manchester Research Explorer

\section{Citation for published version (APA):}

Morgan, K. (2019). Communist history, police history and the archives of British state surveillance. Twentieth Century Communism, 17, 67-89. https://www.Iwbooks.co.uk/twentieth-century-communism/17/communist-historypolice-history

\section{Published in:}

Twentieth Century Communism

\section{Citing this paper}

Please note that where the full-text provided on Manchester Research Explorer is the Author Accepted Manuscript or Proof version this may differ from the final Published version. If citing, it is advised that you check and use the publisher's definitive version.

\section{General rights}

Copyright and moral rights for the publications made accessible in the Research Explorer are retained by the authors and/or other copyright owners and it is a condition of accessing publications that users recognise and abide by the legal requirements associated with these rights.

\section{Takedown policy}

If you believe that this document breaches copyright please refer to the University of Manchester's Takedown Procedures [http://man.ac.uk/04Y6Bo] or contact uml.scholarlycommunications@manchester.ac.uk providing relevant details, so we can investigate your claim.

\section{OPEN ACCESS}




\title{
Communist history, police history and the archives of British state surveillance
}

\section{Kevin Morgan}

\begin{abstract}
In Britain as in other countries security service files have come to provide an important resource for the writing of communist history. This paper discusses some of practical, ethical and methodological challenges they pose for historians. In Britain the selective release of small batches of redacted files was undertaken from the 1990s as part of the post-Cold War rebranding of the MI5 state security service. No meaningful public consultation took place regarding the principles governing the release of these materials. Nor were details made available of the scope of state surveillance or of the individuals and organisations subjected to it. The lack of transparency and accountability was compounded by the asymmetry between observers and observed and the withholding of information regarding the identities, associations and career histories of security operatives. Drawing on published and unpublished examples, the paper characterises this as a project for the 'securitisation' of communist and wider left history: one that seeks to validate MI5's past and continuing role by accentuating issues of espionage while filtering and in many cases destroying evidence of the routine surveillance of political and social movement activism.
\end{abstract}

Keywords: communist archives, MI5, security services, British communist party

With the opening of the Comintern and other communist archives in the early 1990s, a lively discussion took place regarding the uses to be made of such materials and the evidential and methodological challenges to be confronted in doing so. ${ }^{1}$ While different views existed as to what to make of the view from the Comintern archives, one point from which no-one dissented was that they offered crucial insight into the character of the political apparatus which generated them. In Britain since 1997, these materials have been supplemented by the incremental release of selected personal files on communists and others created by the state security services. Assisted by their greater accessibility to historians within Britain, these have if anything been more widely used, with a strong orientation towards questions of espionage. These include biographical studies of considerable scholarship in which the security files figure among the widest possible range of accessible sources. ${ }^{2}$ Nevertheless, discussion of the insights to be drawn from the security files has, with a very few exceptions, been pitched at best at what Brigitte Studer and Berthold Unfried describe (in the context of the Comintern archives) as the 'descriptive positivist approach' to filling in certain evidential gaps. ${ }^{3}$ Comment is frequently made regarding the seemingly inconsequential character of much of the information collected on left-wing activists. Accounts of the apparatus collecting this material have, nevertheless, tended on the whole to be somewhat sanitised if not romanticised and ideologically self-serving. ${ }^{4}$

The discussion that follows is based on a more casual acquaintance with these materials than that of many other historians. ${ }^{5}$ Nevertheless, given the wide availability of selected security files in digitised form, I was struck by the use often made of them without any real evaluation of the particular methodological challenges that they pose. It was also surprising that there should seemingly be so little protest or even comment from concerned historians or historical bodies regarding the absence of proper transparency or accountability regarding these releases and the larger archive from which they are drawn. Journalists following the workings of the secret state were obvious exceptions; but sometimes acerbic commentaries following the release of each latest batch of security files were not followed up 
in more systematic fashion. ${ }^{6}$ The British state has continued to employ scandalously invasive and unaccountable forms of monitoring of environmentalist and other militant groups. The 'century of anti-communisms', already discussed in this journal, involved security practices that not only began long before 1917 but persisted in new forms once communism had ceased to be their primary target.

\section{Enemies of the state?}

A peculiarity of the Communist Party of Great Britain (CPGB) was that it was one of the very few communist parties that was never proscribed by the state. The closest this came to happening was in the winter of 1940-1, as Britain for the time being bore the brunt of the Nazi war offensive. Communists in this period had not merely, like the pacifists, campaigned against the war. They also identified unreservedly with Soviet foreign policy, which in this period was one of friendly collusion (or 'non-aggression') with Germany. Like the fascists, they were seen by the state as jeopardising national security through association with a foreign power. Unlike the fascists, they also belonged to what, until 1943, was a section of a centralised international directed from a foreign capital.

Even so, the treatment of these movements by the state was strikingly different. Already in May 1940, the British Union of Fascists (BUF) had been suppressed and over seven hundred of its members interned. In January 1941 the government did also ban the communist newspaper the Daily Worker, and it sought in other ways to impede the party's functioning. Following careful deliberation at war cabinet level, it nevertheless drew back from the general proscription of communist activities. The CPGB remained a legal party, and with the USSR's entry into the war became a considerably larger one, with over 50,000 members and significant campaigning presence. One could have joined at its formation in 1920 and remained a member until its dissolution without ever having had to operate illegally.

Another of the CPGB's peculiarities was that it was nevertheless the party that within Britain was more continuously, intrusively and systematically monitored by the state than any other political movement - certainly far more so than the fascists. If ministers in 1940-1 were less draconian than they might have been towards the communists, it was not out of some scrupulous regard for their civil liberties. As the cabinet deliberations make clear, the deciding consideration was a pragmatic and somewhat grudging calculation that firmer action risked alienating a much wider constituency of opinion, particularly in the factories. The difficulty, according to minister of labour Ernest Bevin, lay in distinguishing between subversive propaganda and the 'genuine grievances' which communists also pursued, and with which they were publicly identified. Bevin's Labour colleague Herbert Morrison, then home secretary, warned that action against communists might provoke industrial disturbances on a scale akin to those of the First World War. The Conservative Sir John Anderson observed that the communists in any case were quite unlike the fascists in operating in a 'perfectly open manner'. ${ }^{7}$ It did not follow that they would also be dealt with openly. Quite the contrary; it was Anderson himself who at just this moment initiated a restructuring of Britain's secret Security Service (MI5) that included a separate branch for 'countersubversion' and was quickly followed by the installation of bugging devices in the CPGB's King Street headquarters in London's Covent Garden. ${ }^{8}$

If the labelling of extremes was a device for setting the boundaries of the socially and politically acceptable, there were, in the Britain of 1940-1, manifestly differing, conflicting and sometimes rapidly changing views of what these boundaries were. While surveys for Mass-Observation had thus discovered unprecedented levels of public support for the BUF's suppression, respondents were marginally opposed to the ban on the Daily Worker and less 
supportive still of banning the CPGB itself. ${ }^{9}$ On the other hand, while the fascists by now were seen almost universally as lying beyond the bounds of acceptability, this had not been the view of significant sections of the British establishment until at least the mid-1930s. ${ }^{10}$ The communists, conversely, had from the outset been anathema to just those sections of the ruling elite with which the secret state was most closely identified.

The three-way relationship between communism, society and the state was thus one of considerable complexity. Communism in Britain was from the start something of an intersection between a wider culture of labour and radical activism and the networks of the Comintern and the ostensible workers' state at its centre. For Britain's secret intelligence agencies, this translated readily into the language of subversion and sometimes espionage, hence offering rationale or simply pretext for treating communists as potential enemies of the state. Nevertheless, there were also many, in Britain as elsewhere, who looked favourably on the USSR without ever joining the communist party. Many shared the communists' campaigning objectives, whether within or beyond the workplace; and many too passed in and out of the party without abandoning the values and commitments that took them there. These connections were the communists' security in 1940-1. Bevin had wanted to proceed against the 'small number of intellectuals' whom he believed to be the central pivot of communist activity. Nevertheless, ministers judged that the different forms of communist activity were too closely interwoven to allow selective interdiction without extending to the party as a whole. What this breadth of contact also meant was that there was a potentially huge and ill-defined pool of 'sympathisers' which could also be brought within the reach of state surveillance, and which included some of the major cultural and political figures of twentieth-century British history.

Through the prism of the war years, the precariousness of the CPGB's status is glimpsed in sharp relief. Not only during the war but throughout its existence, the CPGB was a legal party subjected to surveillance practices with no proper basis in law. No public approval was required, or obtained, for these practices, nor any public knowledge or scrutiny provided for. An incidental by-product for the historian is that no British political party has ever been so well documented by the state. There is however a far from incidental disadvantage: that access to these documents continues to be governed by unaccountable and secret practices that are exempted from relevant legislation and place the prerogatives of the state above those of any disinterested notion of public interest, individual rights or democratic accountability.

\section{A culture of report}

The Soviet specialist Nicolas Werth has aptly referred to communism as a 'civilisation of report'. ${ }^{11}$ This captures very well the sheer abundance of documentation that the Soviet and Comintern archives revealed after 1991. For a party of the Leninist type, the written word was a crucial instrument of co-ordination, instruction and control. Operating on the principle of democratic centralism, directions were meant to flow continuously from the centre, and reports on their carrying out flow back. For the system's optimal functioning, even the oral exchange of views and information was wherever possible rendered into archivable text to be collated by some higher body. Where this, moreover, was a ruling party, these practices extended to the ancillary movements and activities which in the Soviet case meant those of society as a whole. Through the imagined device of the telescreen, Orwell captured vividly the compulsion for monitoring, recording and thereby controlling which was the essence of the surveillance state. The result for historians of the USSR is a plethora of so-called egodocuments: diaries, confessions, evaluations, self-criticisms, summary biographies, and the records of letters and conversations which the state kept on its own citizens. 
Subject to the obvious limitation of resources, the civilisation of report also extended to the international communist movement and to parties like the CPGB. Among the characteristic practices adopted in Britain by the 1930s were the provision of biographical data by communists of any official standing and the production of full stenographic reports of the meetings of leading party bodies. The difference was that British communists exercised no powers of state surveillance but, on the contrary, were subjected to them with an assiduity that would not have stopped at the telescreen had it been available. With its associated bodies, the CPGB was also the target of numerous police raids and burglaries, which on one occasion (in 1925) even resulted in the publication of selected communist documents at public expense. In their history of inter-war civil liberties, the legal historians Ewing and Gearty comment on the remarkable 'absence of legality' in the conduct of the state or of any sense that its agents should feel constrained by law. ${ }^{12}$

A further consideration not applying in the USSR was the free movement of individuals in and out of the party, taking with them whatever documents they obtained there. For the CPGB, unlike its ruling counterparts, there was therefore no final safeguard against the abstraction of key documents by either state or defecting party member. ${ }^{13}$ At the same time, the political mystique of British communism, like that of any communist party, lay in claims of unity, discipline and unerring rightness that produced a positive obsession with the non-disclosure of internal differences and inconsistencies. The culture of report in these conditions was thus both dependent on documents and liable to be compromised by them; at one and same time it needed everything down on paper and nothing down at all. The resolution of this conundrum, from the early 1920s, lay in the extra-territorial character of the CPGB's ultimate guiding centre. This in any case was where the lines of accountability finally led, and where the machinery existed to digest a truly prodigious supply of text. Until the Comintern's dissolution during the war, this was therefore the one safe repository for British communist documents.

As late as the 1980s one therefore had the curious paradox: that no British party was better documented than the CPGB, and yet no party's historians had fewer documents to work with. This is vividly illustrated by the CPGB's acceptance of the Comintern's anti-war stance in October 1939. Arguably the most controversial episode in the party's history, this not only compromised its anti-fascist credentials but led to a crisis in its relations with other sections of the left and to the removal of its general secretary Harry Pollitt. The deciding debate lasted an entire weekend and every word was captured by stenographers. Thanks to another police raid, the transcript found its way into the custody of the British state as well as the Comintern archives in Moscow. Nevertheless, when forty years later communists revisited the controversy, not even the surviving protagonists had anything to go on but their recollections. ${ }^{14}$ Although Pollitt's anti-fascist sentiments had been vindicated by subsequent events, he too had remained all his life the disciplined party cadre who had no wish to be proven right against the party. Completing a $\mathrm{PhD}$ as late as 1987, the present author was given no access to any of this documentation. It was not until 1990 that the transcript finally saw the light of day as a by-product of Mikhail Gorbachev's glasnost. ${ }^{15}$

The passing of the Cold War thus marked something of an archival revolution and the opening up of what Studer and Unfried describe as an 'Ali-Baba cave-system full of dossiers' ${ }^{16}$ Subject at first to remarkably few restrictions, the files included literally thousands relating either to the CPGB, to its individual members or to associated movements around the party. Though the Comintern archive tails off by the war years, it is from this period that the CPGB itself began to maintain a continuous though far from comprehensive record of its activities. There are obvious parallels with other communist parties like that in France. ${ }^{17}$ Though closed to researchers until the very verge of the CPGB's dissolution, by 
1994 these materials were also accessible to researchers in Manchester's People's History Museum.

The MI5 files in the National Archives are the third major source for communist history to be made available following the break-up of the Soviet bloc. Prior to the 1990s this too would have seemed unthinkable. So distant an episode as the forged Zinoviev letter, the intelligence community's contribution to Labour's 1924 electoral defeat, was still in the 1980s being argued out on partisan lines and without recourse to documentary proofs. ${ }^{18}$ As the USSR followed the Comintern into history, it was nevertheless clear that neither security interests nor ideological warfare offered any credible ground for the continuation of such secrecy. Already in the 1980s, there was a growing public demand for greater transparency sustained by a series of scandals and court actions exposing the abuses and dubious legality of established surveillance practices. Seeking to validate its role in a post-Cold War world, MI5 therefore set about a very well-advertised 'demystification' of its public profile. A policy of 'controlled contact' with the media was followed in 2002 by the appointment of an official historian with some limited scope for strictly controlled disclosure. ${ }^{19}$ It was also as part of this rebranding exercise that the decision was taken in 1997 to begin releasing regular tranches of historical files.

The potential scale of the undertaking is staggering. In 2009 there were said to be almost 400,000 surviving paper files, and at very least a similar number had at various times been disposed of.$^{20}$ In the absence of further information, we cannot tell how many relate to individuals classed as 'communists or suspected communist and Russian sympathisers'. Nevertheless, over the main period of the CPGB's existence this was the one durable core component of MI5's activities. Taken over from Scotland Yard's Special Branch in 1931, it was thereafter regarded as a basic form of induction into the service. As late as the 1980s, still betraying the organisation's military origins and ethos, a senior officer compared investigating communists to 'learning to shoot for a potential infantry officer'. ${ }^{21}$ A typical file derived from these practices may include copies or transcripts of intercepted correspondence; the observations and reports of security personnel; notes of conversations obtained through bugging, tapping and undercover agents; and diverse public documents such as press cuttings. It may also, of course, be redacted to remove any of these items without explanation.

For historians of twentieth-century Britain, the files are a unique and disturbing resource. Britons are not brought up to think of theirs as a civilisation of report. Every individual, whatever their office or political persuasion, may dispose of their personal papers as they see fit, and such prerogatives are even intrinsic to received notions of a liberal political culture. Here, however, a whole class of individuals, many of them making no such provision, have had clandestine state functionaries provide the service for them. In redacting the files, they may protect the identities of their fellow operatives, but show no such compunction regarding the most intimate affairs of their subjects. In every case the collection of this information is without their consent and often it is without their knowledge.

They are a revealing source both for their own times and for our own. Discussing the infiltration of an earlier generation of radicals, E.P. Thompson in The Making of the English Working Class observed that spying was nothing new in Britain but rather an ancient part of British statecraft. ${ }^{22}$ Even so, with the rise of democracy and the broadening into principle of a notion of citizens' rights, such methods had for a time been seen as both morally and politically indefensible. Famously in 1844 , there was a national outcry to learn that the correspondence of the Italian exile Mazzini had been pored over without his consent. In a forthright statement of the prevailing public view, Thomas Carlyle described it as a matter of basic principle 'that sealed letters in an English post-office be, as we all fancied they were, respected as things sacred; that opening of men's letters, a practice near of kin to picking men's pockets ... be not resorted to in England, except in cases of the very last extremity'.23 
Carlyle did allow the possibility of such measures in the event of 'some new Gunpowder Plot ... some double-dyed high treason or imminent national wreck'.

When MI5 was established in 1909, it was at the height of the pre-war German spy scare, and it was on just such grounds that it was equipped with expansive opportunities for letteropening under the new system of Home Office Warrants (HOWs). As subsequently communism displaced the German threat as the principal focus of such activities, the political case for such powers would have been that it too represented just such a plot and potential treason organised on a systematic, well-resourced and continuous basis. As this, however, was a clearly partisan, unavowable and vigorously controvertible rationale - the CPGB was after all a perfectly legal organisation - in practice the routinisation of peacetime political surveillance took place as far as possible in conditions of secrecy.

Though retrospectively it is often overshadowed by the issue of espionage, the one consistent pretext for such activities was subversion. Though a number of espionage cases were brought to trial from the late 1930s, no convincing explanation has been offered as to why supposed proofs of earlier networks had not already resulted in legal proceedings and public exposure. In any case, the routine surveillance of communists not only predated but long postdated any real concerns about espionage, and was later extended to groupings to the CPGB's left that had no significant overseas connections. Whatever subversion meant, communists were clearly setting about it in the most insidious ways. Certainly, the defence of the realm was in a fragile state if it needed a special note to the BBC to warn that the Christopher Hill about to broadcast on the seventeenth-century Barebones Parliament was not merely a well-known historian but a communist. ${ }^{24}$

Subversion, in any case, was not defined even in general terms until 1972. In practice this meant leaving it to the covert deliberations of the intelligence community itself to decide who and what was included. For much of the inter-war period this meant sweeping in leftists, including premature anti-fascists and anti-fascsist refugees, without unduly impinging on the patriotic right. It is a remarkable fact that, while hundreds of now-forgotten communist activists experienced invasive surveillance, Oswald Mosley could for eight years head the BUF and have Hitler among his wedding guests without yet having his correspondence tampered with.

It was successive home secretaries who declined to authorise a Home Office Warrant on Mosley. Other departments like the Foreign Office and Home Office have shown a scandalous predilection for withholding or disposing of files in matters of national and international public interest. ${ }^{25}$ It would therefore be a mistake to focus only on MI5 rather than the wider political environment within which it was and is still located. Maxwell Knight, who in this period took the lead in MI5's penetration of the CPGB, is sometimes evoked with an aura somewhat reminiscent of Ian Fleming or even John Buchan. The fact remains tat Knight had for a number of years carried out similar activities while holding high office in the British Fascists. Recommended for state employment by the vicious anti-Semite and conspiracy theorist Nesta Webster, Knight was an out-and-out anti-democrat whose credentials included the infiltration of the CPGB by fascist agents and the burgling of perfectly legal premises for an anti-trade union agency funded by private business interests. These were not impediments to his further employment by the official wing of the movement; they were positive recommendations, and there was evidently a time-lag, still to be fully investigated, before Knight came to see the case for using such methods against the fascists themselves. ${ }^{26}$

An MI5 prosopography might offer a fascinating insight into how typical or otherwise such forms of attachment and association actually were. It would doubtless prove particularly illuminating to trace the career trajectories of its officers through various forms of military and colonial service - which the most recent describes as an innocent case of aptitude, 
availability and esprit de corps. ${ }^{27}$ As Bernard Porter has observed, this is a missing dimension of intelligence history that matters all the more given how far MI5's activities were guided by its own esoteric worldview rather than any wider notion of accountability. ${ }^{28}$ However, in a remarkable case of asymmetry between observers and observed, these identities and career histories, unlike the communists', remain for the most part as closely guarded state secrets.

Not surprisingly, there is limited discussion of these issues in the official MI5 history by Christopher Andrew. In an acerbic review of the authorised history of its Australian counterpart, the Australian Security and Intelligence Organisation (ASIO), Ernst Willheim identifies five key issues which it fails to deal with adequately:

- analysis of ASIO's budget and how that budget was allocated;

- analysis of ASIO's policies, policy development and priorities;

- description of how ASIO recuited staff and agents;

- the lack of surveillance of right wing extremists;

- analysis of the impact of ASIO's surveillance activities on the Australian community. ${ }^{29}$

These are just the areas in which Andrew's account is also most constrained. When the commission for the project was announced, there was some suggestion that it would be subject to the usual guarantees of historical rigour, namely the 'dialectic of [the] discipline' and the ability of other historians to offer corrective or counter-argument on the basis of the same materials. ${ }^{30}$ That, of course, is an opportunity we are still awaiting. Meanwhile, one is once more up against the closed wall of 'trustworthiness' which had one had sometimes encountered in the case of communist themselves, only then it was likely to be referred to as conspiracy. The very titles of these official histories, Defence of the Realm and The Spy Catchers, are like a self-serving gloss on organisations whose continuing lack of proportion, transparency and accountability poses deeply troubling questions regarding the biases and modi operandi of ostensibly liberal states.

Historians have never been able simply to choose a subject of research and call up the necessary papers. Referring to the Comintern archives, Studer and Unfried warn against researchers reproducing the 'policeman's view of history' they will find there. ${ }^{31}$ Carlyle, one imagines, might also have inveighed against the handling of stolen goods. Nevertheless, Carlyle also understood that historians of radical movements have to seize on whatever documents they can come by. 'Governing Persons, were they never so insignificant intrinsically, have for the most part plenty of Memoir-writers', he wrote of the toppling of France's ancien régime. 'Not so with these Governing Persons, now in the Town hall!'32 Trotsky in his autobiography dreamt of a 'cinematic record of modern parliamentarism', but with the cameras installed, not at the parliamentary podium, but in offices and private places, and running over 'the secret correspondence of the party leaders'. ${ }^{33}$

It was a fantasy, of course; it is the ruling powers that have the cameras and the parties of revolt that have their correspondence photographed. So much is secrecy an attribute of power that it is these permanently oppositional movements, ironically, that are in many ways better documented than any of their more mainstream counterparts. As with any cinematic record, we merely need to keep in mind who it was that wielded the camera, and who decides which footage we get to see.

\section{Police biography}

In December 1934, the communist writer Ralph Fox wrote in satirical vein to the New Statesman concerning the unfair advantage his biographers would have over those of his 
contemporaries. 'For I have reason to believe', Fox explained, 'that for many years now earnest investigation officers in the Post Office have read every scrap of my correspondence before delivering it.' Other earnest officers had doggedly tracked Fox's movements and his personal contacts, and found a constant source of instruction in his telephone conversations. The task of Fox's biographers was therefore simplified into that of obtaining the relevant files from the archives of the state. It being a well-established fact that 'police evidence is the only kind which is infallible', biography - 'police biography', no less - would at last be elevated to the status of a science. ${ }^{34}$

As Fox anticipated, the present author has enjoyed precisely these advantages in compiling Fox's entry for the Oxford Dictionary of National Biography. Killed fighting in Spain in 1936, Fox did not as far as we know leave any personal papers. He was, more than most communists, a public figure whose writings include much journalism and several books. Through two spells working in Moscow, he has also left significant traces in the Comintern archives. Nevertheless, the MI5 files released in 2003 add significant further insight into the complexity of his commitments as one of the foremost communist intellectuals of his time. Fox himself would not have hesitated to use such a resource. Having recently published a life of that 'rather low foreign personage' Lenin, in his letter to the Statesman he described having drawn on just caches of the tsarist secret police, the 'revolution having thrown them open to the vulgar'. ${ }^{35}$ Historians of low personages have always had to be resourceful in the use of evidence; often it is state agencies that have had the resources and motivation to document them best. Like Fox in Russia, we are free to read these papers against the grain without having to reproduce the 'policeman's view'. But this does as always require critical reflection on how these archives came to be constructed in the form now made available to us.

There is a lesser order of question at the level of the individual file or subject. Here there is the obvious issue of what sorts of information the compilers sought to record, through which of the available forms of data-gathering, and how this has since been redacted. There is also the issue of how far the subject of the files sought to avoid having recorded just the sorts of information that their uninvited confidants were interested in. Users of the files have certainly remarked on how much purely personal or even trivial information they contain. A communist peace activist of the 1950s has left elsewhere a remarkable collection of letters ranging freely over her beliefs, her daily tribulations and her most intimate personal relationships. 'I bet the entire world and MI5 know about us', she writes to her communist lover, 'and what is more I am proud of it.' But in another letter she refrains from so much as mentioning another comrade's name, because 'one never knows who reads our letters' ${ }^{36}$

Of its nature, there is usually only negative eveidence of this type. Caught in a purely personal conversation around the same time, the historian Rodney Hilton wonders 'whether the little friend who opened his letters was listening to this telephone'. When his interlocutor admits to feeling shaken at the thought of her unguarded loquaciousness, Hilton urges that it was "no good taking any notice of "them"'; even so, one wonder whether he would have been so cavalier had they been discussing the matters of political sensitivity that their listeners were presumably keenest to record. ${ }^{37}$ On Fox's files the several HOWs taken out are justified in 1934 as having produced 'interesting and useful information' regarding both the open and covert aspects of communist activities. Typed extracts from both public and private sources reveal much that is also 'interesting and useful' to historians, including insights into political differences within the CPGB that may not be documented elsewhere. Nevertheless, the only covert activities revealed are of a purely personal character and not traditionally thought the business of the state.

Insights from other sources can sometimes help to clarify the sorts of information the files may not contain as well as what they do. In the early 1990s, the former Daily Worker 
journalist Sam Russell told of how in 1952 he returned from Prague having attended the infamous Slansky show trial. Among the trial's predominantly Jewish victims were communists who during their wartime London exile had had the closest relations with their British counterparts, and in one case even married a British party member. Russell described how Pollitt took him onto the King Street staircase, believing it to be free of bugging devices. Quizzing him about the victims' demeanour, he then insisted on his absolute disbelief in Slansky's confession of treachery. ${ }^{38}$ Pollitt never wavered publicly on the issue and the admission of private doubt cannot be said to reflect well on him. We can, however, only speculate as to why, and from whom, he should have concealed what was in the end a mere expression of opinion with no legal or security implications. Earlier indiscretions are certainly recorded on his Comintern file, while MI5 itself had urged publication of the compromising debate over the war in which Pollitt had expressed such forthright misgivings. All that we know for sure is that the exchange is not recorded on either Pollitt's or Russell's MI5 file.

James Friell was another Daily Worker journalist, better known as the cartoonist Gabriel. He recalled how in 1938-9 'MI5 people' were constantly standing outside party offices ready to tail off and follow you as you left. 'They didn't attempt to disguise it, I mean it was meant to disconcert you as much as anything.' One evening, Pollitt was working late at the paper and phoned another of the party's leading figure, R. Palme Dutt: "Raji, now get off your woman, I want to talk to you." Of course, he couldn't say much over the bloody phone, the phone was tapped.' Together Pollitt and Dutt went to King Street with Eva Reckitt, one of the 'monied party types' owning a car, and with Friell's assistance they loaded it up with papers and drove with them into the night - 'I don't know where, I wasn't used to driving cars through the night'. Though otherwise uninvolved in matters of conspiracy, Friell stressed how right they were to take such action 'because the whole list of the membership of the party would be in there and what-not, which people didn't know about'. ${ }^{39}$ The state would, thanks to MI5's 'Operation Party Piece', come to know a good deal more later. But Friell's account is meanwhile consistent with the sharp decline in the transfer of documents to Moscow before the war, but without, for the time being, any corresponding increase in those retained by the party in Britain itself. ${ }^{40}$

A more serious issue for the researcher is the absence of transparency, accountability or system in MI5's programme of six-monthly releases. The difference with Russia after 1917 is that there has of course been no revolution, nor even the pretence of consultation with the vulgar. An Operational Selection Policy (OSP) was produced in 2001, providing generic guidance for the preservation of selected historical files and none at all for their release into the public domain. The main priority groups identified are senior officials of 'subversive' parties, targets of 'intrusive' surveillance, agents of hostile intelligence, any individual or their relative not given security clearance, and those achieving positions of 'public eminence'. ${ }^{41}$ No information is provided as to the number of individuals falling within each class, and Andrew's voluminous official history does not even contain such basic information as a listing over time of the bodies that were deemed subversive. Andrew alone been granted access to such information, but under conditions of confidentiality and with past and present intelligence officers guiding him through the huge number of files that no single historian could possibly digest. No other historian is able to request a file, or even to establish that it exists, or has existed, as Eric Hobsbawm was able to confirm on being denied access to his own. Hobsbawm's files have, as it happens, been made accessible since his death, subject to what appears to be an implicit fifty-year rule. By policy or good fortune it appears that we are not (except by oversight) to have the benefit of any subject of a file being able to comment upon its contents. 
Of the more than 400,000 files that have been incinerated, half at least went with unseemly haste under the 'review and destruction' policy introduced following the ending of the Cold War. This principally applies to targets of 'counter-subversion', and the OSP merely sets out the object of retaining a relatively tiny number of files not meeting any of its other criteria. MI5 remains exempt from the provisions of the 2000 Freedom of Information Act even in respect of historical files. It retains complete control over its own records and has never engaged in any public consultation with specialists having either an interest or an expertise in radical political movements. Its role in recent British history remains controversial and it makes no secret (for a change) of its manifest continuing interest in the validation of its historical role as a form of public advocacy in a post-Cold War world.

The wider aspect of these questions may not immediately concern the users of these files. What does obviously concern the researcher is the fact that some files may be read comfortably at home while many more have been are destroyed without any public trace. Through the combination of selective release, wholesale destruction and the energetic management of MI5's public reputation, the reader is steered towards a heightened sense of security threats in which the legitimacy of the organisation is seen to lie. This is reinforced by the wider visibility of the spy as cautionary tale that one may take in almost unconsciously. '[O]thers still - one thinks immediately of the Cambridge spies like Kim Philby - had drifted to communism', writes so eminent a historian as Jonathan Haslam of the 1930s, as if this were the overriding meaning of the years of anti-fascist radicalisation, and in a context which does not otherwise touch on espionage. ${ }^{42}$

At the same time, the files will now never be made available that would reveal the sheer extent of MI5's covert surveillance of legitimate political activities, whether carried out by communists or others. 'As a Party family we were only two degrees of separation away from the biggest spy story of the century', writes one recent memoirist, adding that in keeping communists under surveillance the behaviour of the security services had been 'merely sensible'. ${ }^{43}$ One may again wonder whether we are not being led a little too easily in this direction. A principle of two degrees of separation, if taken at face value, would certainly justify McCarthyism and the wreckage of careers and human lives that it caused. Applied to the challenge of political Islam, with which that of Cold War communism is routinely likened in this literature, the implications in terms of community relations would be disturbing indeed. We should remember the instincts of that section of the population which in 1940-1 believed that any attack on such activities was an attack on democracy itself. In line with the wider securitisation of public discourse, we need to be wary both of the securitisation of the history of the radical left and of the normalisation of extra-legal techniques for its continuous monitoring.

In just the spirit which Thompson recommended, we not only need to read between the lines of these reports, as we would of any such document, but to keep in mind the reports that were never made or which have since been despatched to the memory-hole. We will never, for better or worse, have telephone intercepts on the Conservative Party's financial affairs, or on its contacts with unelected power-holders in the City, or on the sense of fellowfeeling with leaders like Mussolini with whom Britain did eventually (unlike the USSR) end up at war. We therefore need to watch out for a 'secret world' conception of history that can only be applied to left-wing political radicals. One might cite, as a final example, cite the security files on the sometime communist and well-known labour journalist W.N. Ewer. Ewer's files were released in October 2002 and within fifteen months an article drawing upon them had been published by a then PhD student of MI5's official historian. No wider research was drawn upon, and in a subsequent contribution to the same journal it was argued that the article's publication did not meet the normal canons of historical research nor subject to the usual critical scrutiny such obviously partial sources as Maxwell Knight. ${ }^{44}$ The specific 
points at issue can be left to the reader to decide: thanks to Ewer's relative notoriety, the 'dialectic of the discipline' could in this instance function through the more widely accessible documentation of some at least of the different aspects of his very public career.

Nevertheless, the basic points are ones of wider application: that the exercising of such highly restricted forms of access in the case of an organisation whose operating principle is dissimulation ('neither confirm nor deny') should least be of all be exempted from routine critical research procedures; and that in using the archives of any organisation, we must first of all come to terms with the nature of that organisation itself.

\footnotetext{
${ }^{1}$ See for example Serge Wolikow (ed.), Une histoire en révolution? Du bon usage des archives, de Moscou et d'ailleurs, Dijon: Presses universitaires de Bourgogne, 1996.

${ }^{2}$ For example Geoff Andrews, Shadow Man: at the heart of the Cambridge spy circle, London: Tauris, 2016.

${ }^{3}$ Brigitte Studer and Berthold Unfried, 'At the beginning of history. Visions of the Comintern after the opening of the archives', International Review of Social History, 42 (1997), 421.

${ }^{4}$ The most clear-cut recent example is Richard Davenport-Hines, Enemies Within. Communists, the Cambridge spies and the making of modern Britain (London: Collins, 2019 edn).

${ }^{5}$ The account that follows draws extensively on an essay commissioned for the Gale digital archive on 'Political extremism and radicalism in the twentieth century'. I am grateful to Gale for allowing me to contribute a commentary that was several times longer than that originally commissioned while expressing a dissenting view of a number of the issues involved in using these materials.

${ }^{6}$ Authoritative commentaries on many of the issues discussed here include R.C. Thurlow, 'The historiography and source materials in the study of internal security in modern Britain (1885-1956)', History Compass, vi (2007), 147-71; also idem, 'Passive and active anti-fascism: the state and national security, 1923-45' in Copsey and Olechnowicz, Varieties, 162-80. In part these accounts update the same author's The Secret State: British internal security in the twentieth century (Oxford, 1995) which remains of considerable use. Jennifer Luff is also producing important work in this field, for example 'Covert and overt operations: interwar political policing in the US and the UK', American Historical Review, 122, 3 (2017), 727-57.

${ }^{7}$ Kevin Morgan, Against Fascism and War: ruptures and continuities in British communist politics 1935-41, Manchester: Manchester University Press, 1989, 240.

${ }^{8}$ Of necessity, the account that follows draws much factual information from the authorise history of Christopher Andrew, The Defence of the Realm: the authorized history of MI5, London: Allen Lane, 2009. While this contains much interesting information, the constraints under which it was undertaken mean that rather more information is excluded which as yet remains beyond the reach of independent scholarship. Andrew's history provides no references for files still held by MI5, nor any details of those destroyed, nor any hard data as to the individuals and organisations targeted by the state. There is still no independent way of corroborating Andrew's account or exploring those aspects of MI5's history that are addressed either perfunctorily or not at all.

${ }^{9}$ Mass-Observation Archive, University of Sussex, file reports 135 ('Reactions to internment of Mosley', 23 May 1940) and 552 ('The banning of "The Daily Worker"', 23 Jan 1941) accessible at http://massobservation.amdigital.co.uk/documents/

${ }^{10}$ Forthright expositions of this view include Richard Griffiths, Fellow-Travellers of the Right, Oxford: Oxford University Press, 1983 edn; Martin Pugh, 'Hurrah for the Blackshitys!', London: Cape, 2005. For a sceptical reponse, see Philip Williamson, 'The Conservative Party, fascism and anti-fascism' in Nigel Copsey and Andrzej Olechnowicz (eds), Varieties of Anti-Fascism. Britain in the inter-war period, Basingstoke: Palgrave Macmillan, 2010, 73-97.

${ }^{11}$ Werth cited Brigitte Studer, The Transnational World of the Cominternians, Basingstoke: Palgrave Macmillan, 2015, 16.

12 K.D. Ewing and C.A. Gearty, The Struggle for Civil Liberties. Political freedom and the rule of law in Britain 1914-1945, Oxford: Oxford University Press, 2000, 152-3.

13 Though there are fewer examples of the latter than, say, in France, they do nevertheless include the Graham Polland papers in the Bodleian Library which provide one of the fullest documentations of local-level communism in the Britain of the 1920s. Henry Hemming, M: Maxwell Knight, MI5's greatest spy master, London: Penguin, 2017, maintains that Pollard was an informant working for the security services.

${ }^{14}$ John Attfield and Stephen Williams (eds), 1939. The Communist Party and the war, London: Lawrence \& Wishart, 1984.
} 
${ }^{15}$ Francis King and George Matthews (eds), About Turn. The British Communist Party and the Second World War. The verbatim record of the Central Committee meetings of 25 September and 2-3 October 1939, London: Lawrence \& Wishart, 1990.

${ }^{16}$ Studer and Unfried, 'At the beginning of history'.

${ }^{17}$ Frédéric Genevée, La fin du secret: histoire des archives du Parti communiste français (Paris: Éditions de l'Atelier, 2012).

${ }^{18}$ Albeit as recently as 2017 it was reported that one file on the episode had been lost after the Home Office fremoved it for some unexplained purpose (Ian Cobain, 'Government admits "losing" thousands of papers from National Archives', Guardian, 26 Dec. 2017).

19 Andrew, Defence of the Realm, 777.

${ }^{20}$ The official advice on the release and retention of these files indicates that nearly 4,000 files have been transferred in whole or part to the National Archives, as compared with 'over 175,00' destroyed before the early 1970s, when a policy of indefinite retention was decided upon, and 'about 200,000' destroyed when the reviewand-destruction policy was reinstated following the collapse of the USSR. 'Most of the files destroyed had been opened for counter-subversion reasons, and retained because Soviet and Warsaw Pact intelligence services had in the past sought to recruit spies from within certain subversive groups.'

(http://webarchive.nationalarchives.gov.uk/20110805071645/https://www.mi5.gov.uk/output/retention-anddestruction-of-files.html, accessed 26 Apr. 2018.

${ }^{21}$ Andrew, Defence of the Realm, 561.

${ }^{22}$ E.P. Thompson, The Making of the English Working Class, London: Gollancz, 1963, 484-97.

${ }^{23}$ Carlyle writing to the Times, 18 June 1844, cited Richard Herne Shepherd, Memoirs of the Life and Writings of Thomas Carlyle, London: W.H. Allen, 1881, vol. 1, 299-301.

${ }^{24}$ KV 2/3943, N. Dabell to N.E. Wadsley, BBC, 19 May 1953. Happily the BBC's reponse (from G.M. Lewis, 27 May 1953) was that the talk should be allowed to stand on its merits.

${ }^{25}$ See for example Ian Cobain, 'Foreign Office hiding $1 \mathrm{~m}$. historic files in secret archive', Guardian, 18 Oct. 2013.

${ }^{26}$ Knight's political affiliations are discussed in John. G. Hope, 'Surveillance or collusion? Maxwell Knight, MI5 and the British Fascisti', Intelligence and National Security, 9, 4 (1994), 651-75.

${ }^{27}$ Davenport-Hines, Enemies, 68.

${ }^{28}$ Bernard Porter, 'Other people's mail', London Review of Books, 19 Nov. 2009, 15-17.

${ }^{29}$ Ernst Willheim, 'Is David Horner's official history of ASIO “honest history? Was Colonel Spry a traitor?', Honest History, 14 Apr. 2015, accessed at http://honesthistory.net.au/wp/is-david-horners-official-history-ofasio-honest-history/

${ }^{30}$ David Walker, 'Just how intelligent?', Guardian, 18 Feb. 2003.

${ }^{31}$ Studer and Unfried, 'At the beginning', 424-5.

32 Thomas Carlyle, The French Revolution. Volume II: The Guillotine. London, 1871 edn, 6

${ }^{33}$ Leon Trotsky, My Life. An attempt at autobiography, Harmondsworth: Penguin, 1975 edn, 511.

${ }^{34}$ Fox, 'Police biography', New Statesman and Nation, 29 Dec. 1934, 966-7.

${ }^{35}$ See Ralph Fox, Lenin: a biography, Gollancz, 1933.

${ }^{36}$ Frow archives, Working Class Movement Library, Salford: Ruth to Edmund Frow, 4 Oct. 1953 and 15 Mar. 1954.

${ }^{37}$ NA KV 2/4297/88, telecheck 24 Jan. 1952.

${ }^{38}$ Author's interview with Sam Russell, 2 Sept. 1992. A document in Russell's security file records that it had been 'discreetly ascertained' that he was at the Prague trial. 'He said that he was personally acquainted with two of the prisoners (who had been sentenced to death), and was amazed at the confessions made by the accused when in the dock. He found it extremely difficult to believe that they admitted to so many crimes.' (NA KV 2/3746/72, note of 29 Nov. 1952. For Russell's wider experiences as a journalist, see his 'Moscow-HavanaPrague: recollections of a communist foreign correspondent', Twentieth Century Communism, 3 (2011), 148-74. ${ }^{39}$ Author's interview with James Friell, 28 Aug. 1988.

${ }^{40}$ A key consideration the damaging effect of the Moscow purges on the Comintern apparatus. In his book The Palestine Communist Party 1919-1948. Arab and Jew in the struggle for internationalism (Chicago, IL: Haymarket, 2010 edn, 73 and 201 n108), Musa Budeiri describes how in this period contacts with the Comintern were severely weakened for precisely this reason. In the CPGB's case, it is interesting that the transcript of the September 1938 party congress is the first not to have been sent to Moscow and is still accessible in the national party archives in Manchester. Papers such as Friell describes, on the other hand, are not.

${ }^{41}$ Operation Selection Policy OSP8, revised Nov. 2005 and accessible at https://www.nationalarchives.gov.uk/documents/information-management/osp8.pdf.

42 Jonathan Haslam, The Vices of Integrity: E.H. Carr, 1892-1982 (London: Verso, 1999), 73.

${ }^{43}$ David Aaronovitch, Party Animals: my family and other communists, London, Vintage, 2016, 224. 
${ }^{44}$ Victor Madeira, 'Moscow interwar infiltration of British intelligence', Historical Journal, 46, 4 (2003), 915 33; John Callaghan and Kevin Morgan, 'The open conspiracy of the Communist Party and the case of W. N. Ewer, communist and anti-communist', Historical Journal, 49, 2 (2006), 549-64. 